\title{
Intravenous albumin infusion is an effective therapy for hyponatraemia in cirrhotic patients with ascites
}

\author{
P A McCormick, P Mistry, G Kaye, A K Burroughs, N McIntyre
}

\begin{abstract}
The treatment of moderate to severe hyponatraemia in patients with decompensated liver disease is unsatisfactory. We report our preliminary experience using intravenous infusion of albumin to treat this condition. Three patients with cirrhosis, ascites, and hyponatraemia responded satisfactorily to treatment; one patient with fulminant hepatitis $B$ did not respond. Intravenous albumin infusion is a safe and effective therapy for patients with cirrhosis complicated by hyponatraemia. Its main role may be in preparing patients for surgery, particularly liver transplantation.
\end{abstract}

Hyponatraemia is a common complication in cirrhotic patients with ascites and is associated with a poor prognosis particularly if there is associated renal impairment.' As prolonged hyponatraemia of even modest degree $(125 \mathrm{mmol} / \mathrm{l})$ may result in irreversible neurological damage ${ }^{2}$ it has been suggested that hyponatraemia should be treated in patients with liver disease once the serum sodium falls below $130 \mathrm{mmol} / \mathrm{l}^{3}$ Various treatments have been recommended including vigorous fluid restriction, ${ }^{3}$ peritoneal dialysis, ${ }^{4}$ haemofiltration, ${ }^{5}$ oral administration of urea $^{6}$ and oral tetracycline. ${ }^{7}$ These treatments are in many cases unpleasant or potentially toxic. The demonstration that urinary free water clearance can be improved in some cirrhotics by volume expansion with intravenous albumin and saline ${ }^{8}$ and that intravenous albumin may improve hyponatraemia in non-cirrhotic hyponatraemic patients ${ }^{9}$ prompted us to try this therapy in hyponatraemia cirrhotic patients. We describe our preliminary experience with this treatment in four consecutive patients with significant hyponatraemia.

Albumin is available as $5 \%$ and $20 \%$ solutions for infusion. One litre of 5\% solution contains 50 g albumin and approximately $130 \mathrm{mmol}$ sodium. A similar amount of albumin is contained in 250 $\mathrm{ml} 20 \%$ solution along with approximately 33 mmol sodium. Both solutions were used in this study but the $20 \%$ preparation was preferred as it involved the infusion of less salt and water.

Address for correspondence: Dr P A McCormick, Academi Department of Medicine, Royal Free Hospital, Pon Street, London NW3 2QG

Accepted for publication 22 May 1989

PATIENT I

In October 1987 a 50 year old man was found to have HBsAg positive cirrhosis. Over the next four months he was admitted twice with variceal bleeding and treated with emergency sclerotherapy. In March 1988 he was admitted with spontaneous bacterial peritonitis, and found to be deeply jaundiced with marked ascites. Serum bilirubin was $95 \mu \mathrm{mol} / \mathrm{l}$, serum albumin $35 \mathrm{~g} / \mathrm{l}$, prothrombin time 19 seconds (normal range 12 16) and serum sodium $133 \mathrm{mmol} / \mathrm{l}$. Child-Pugh grade was $\mathrm{C}$ with a score of $10{ }^{10} \mathrm{He}$ had a long protracted hospital course complicated by recurrent episodes of spontaneous bacterial peritonitis, hepatic encephalopathy, pneumonia and variceal bleeding. The ascites was unresponsive to diuretic therapy. During April he became hyponatraemic and all diuretics were stopped. Despite this his serum sodium failed to increase and three weeks later fell to $117 \mathrm{mmol} / \mathrm{l}$. Serum albumin at this point was $34 \mathrm{~g} / \mathrm{l}$. A Hickman catheter was inserted and intravenous feeding begun. His ascites was treated with paracentesis and intravenous albumin infusions and it was noticed that the serum sodium tended to rise after each treatment session. A trial of regular albumin infusions with or without paracentesis was started. Over a three week period his serum sodium rose from $117 \mathrm{mmol} / 1$ to $139 \mathrm{mmol} / \mathrm{l}$ and was maintained in the normal range with intravenous albumin despite the occurrence of a small variceal haemorrhage (Fig 1). In view of this improvement he was considered for liver transplantation but died while awaiting a suitable donor.
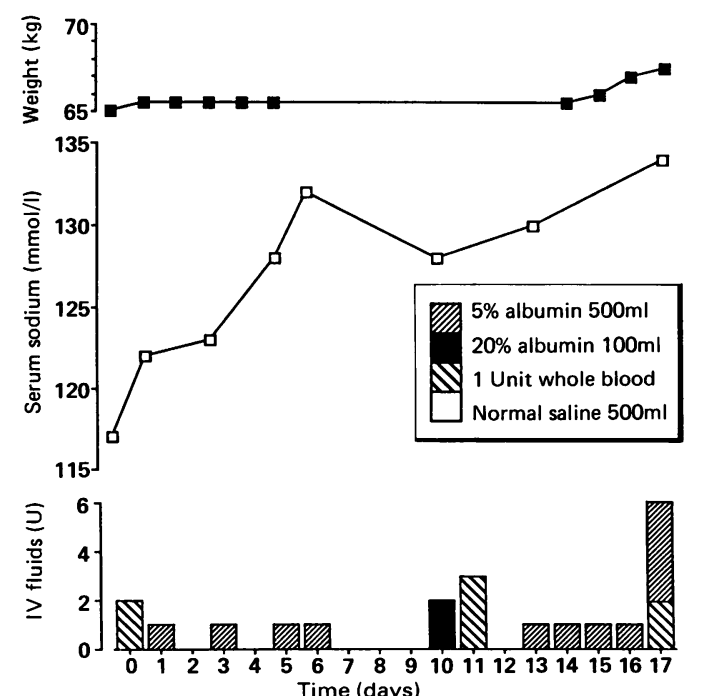


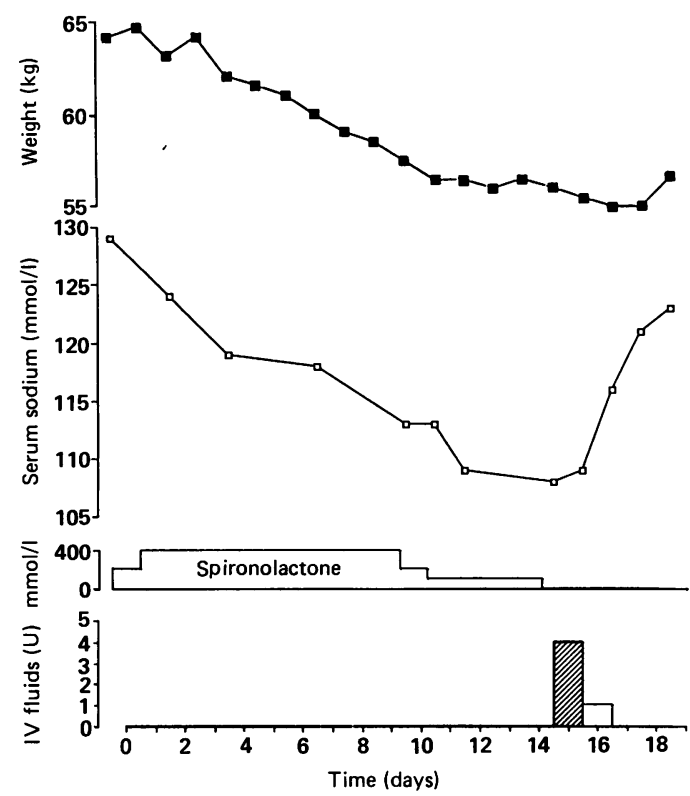

Figure 2: Time course of changes in serum sodium in patient 2.

PATIENT 2

A 67 year old woman was admitted in May 1988 with refractory ascites. One year previously cryptogenic ascites was diagnosed when she presented with variceal bleeding. An oesophageal transection was performed followed by periodic variceal sclerotherapy to prevent rebleeding. Two months before admission she was admitted to another hospital with spontaneous bacterial peritonitis.

On admission she had marked ascites and mild hepatic encephalopathy. Ascitic tap revealed no evidence of infection. Serum albumin was $34 \mathrm{~g} / \mathrm{l}$, serum bilirubin $68 \mu \mathrm{mol} / \mathrm{l}$ and prothrombin times 17 seconds. Child/Pugh grade was $C$ with a score of 11 . To control the ascites the dose of spironolactone was increased
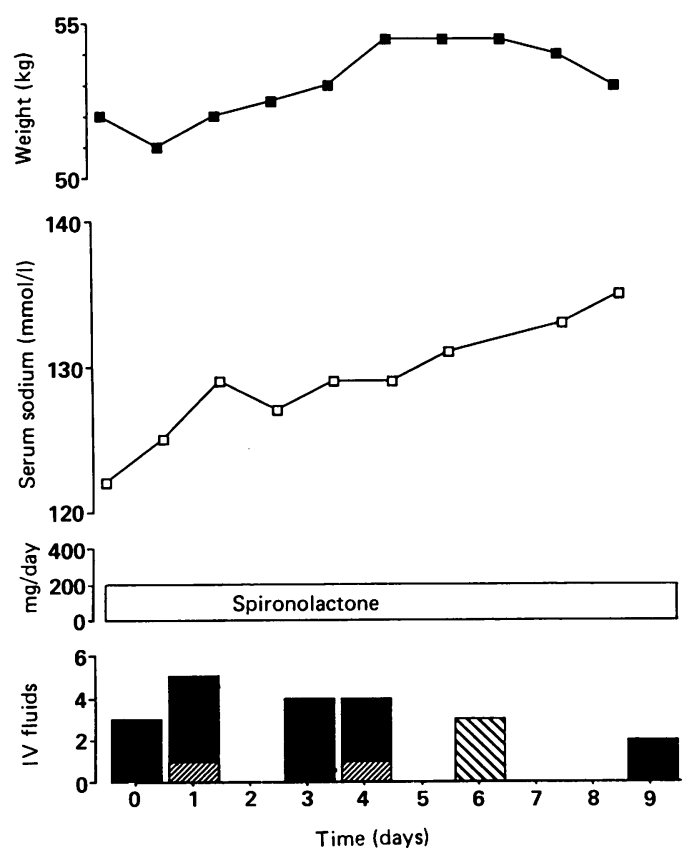

Figure 3: Time course of changes in serum sodium in patient 3. from 200 to $400 \mathrm{mg} /$ day. Over a week the serum sodium fell progressively from $129 \mathrm{mmol} / \mathrm{l}$ to 114 $\mathrm{mmol} / \mathrm{l}$ (Fig 2). Despite reducing the spironolactone to $100 \mathrm{mg} /$ day and limiting her fluid intake to $750 \mathrm{ml} /$ day the serum sodium fell further to $108 \mathrm{mmol} / \mathrm{l}$. At this point she had marked postural hypotension and was too weak to stand unaided. Spironolactone was stopped and four units of $5 \%$ albumin and $500 \mathrm{ml}$ normal saline were given intravenously. Her serum sodium rose from $108 \mathrm{mmol} / \mathrm{l}$ to $121 \mathrm{mmol} / \mathrm{lover}$ three days. As the infused solutions contained about $340 \mathrm{mmol}$ sodium and her calculated extracellular volume was $20 \mathrm{l}$ it is obvious that the rise in serum sodium was not solely the result of the infusion of sodium. Along with the rise in serum sodium there was a dramatic improvement in her general well being and she was able to leave hospital to attend an important family celebration. The former dose of $200 \mathrm{mg}$ spironolactone was reommenced with no further fall in the serum sodium.

Six months later she was readmitted with gross ascites and a serum sodium of $126 \mathrm{mmol} / \mathrm{l}$. She had been taking spironolactone $400 \mathrm{mg}$ and frusemide $80 \mathrm{mg}$ a day as an out-patient. On this occasion we continued her diuretics and measured free water clearance before and after the intravenous infusion of $60 \mathrm{~g}$ albumin $(20 \%$ solution) over two hours. Serum osmolality remained essentially unchanged at $263 \mathrm{mOsmol}$ before and $259 \mathrm{mOsmol}$ after the infusion. Urinary osmolality decreased significantly from $458 \mathrm{mOsmol}$ to $259 \mathrm{mOsmol}$ with increase in free water clearance from $-0.38 \mathrm{ml} / \mathrm{min}$ to $-0.02 \mathrm{ml} /$ $\min$.

\section{PATIENT 3}

A 65 year old woman with primary biliary cirrhosis was admitted in June 1988 with progressive jaundice, anorexia, and fatigue. A portocaval shunt was performed three months previously because of frequent severe variceal bleeds. On admission her serum bilirubin was $408 \mu \mathrm{mol} / \mathrm{l}$, serum albumin $27 \mathrm{~g} / \mathrm{l}$ and prothrombin time 19 seconds with a Child-Pugh grade of C (score 10). Investigations showed that the shunt was patent and there was no evidence of hepatocellular carcinoma. She was markedly hyponatraemic with a serum sodium of 122 $\mathrm{mmol} / \mathrm{l}$ (Fig 3). Daily medications on admission included spironolactone $200 \mathrm{mg} / \mathrm{day}$, ranitidine $300 \mathrm{mg} /$ day, thyroxine $100 \mu \mathrm{g} /$ day and digoxin $0 \cdot 125 \mathrm{mg} /$ day. No changes were made to her medications and she was treated with intravenous infusions of $5 \%$ and $20 \%$ albumin. On this regimen the serum sodium rose rapidly to 129 followed by a slower rise to $135 \mathrm{mmol} / \mathrm{l}$. Her haemoglobin was $12.4 \mathrm{~g} / \mathrm{l}$ on admission but subsequently fell to $9.4 \mathrm{~g} / \mathrm{l}$ presumably because of haemodilution as there was no evidence of blood loss. A three unit whole blood transfusion was given. One week after discharge the serum sodium was $134 \mathrm{mmol} / \mathrm{l}$ but one month later it had fallen to $127 \mathrm{mmol} / \mathrm{l}$ requiring further infusions of albumin. She was subsequently successfully treated with intermittent infusions of albumin as an outpatient but finally died of liver faiure in December 1988. 

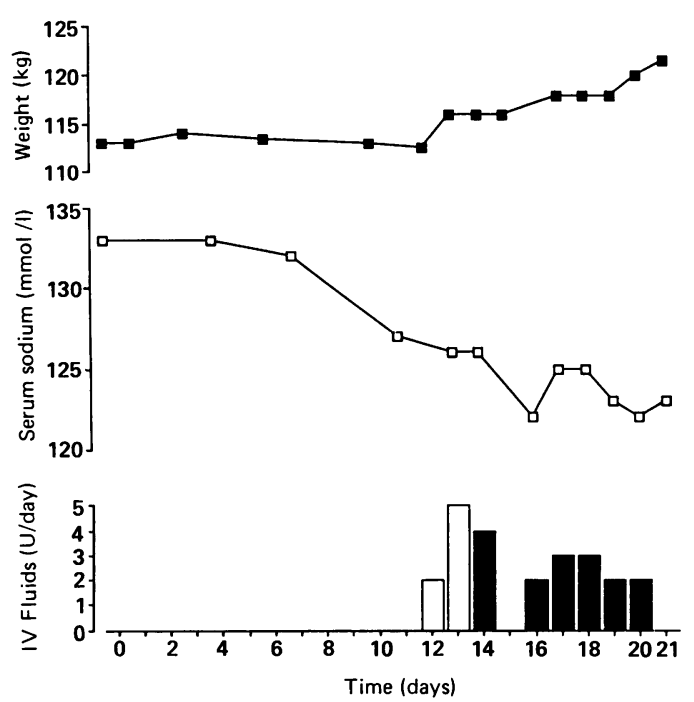

Figure 4: Time course of changes in serum sodium of patient 4.

\section{PATIENT 4}

A 49 year old woman was admitted in May 1988 with acute hepatitis B. She had been unwell for three weeks with anorexia, nausea and vomiting and became jaundiced one week before admission. Her husband was known to be a carrier of hepatitis B. In 1987 breast cancer with axillary node involvement was diagnosed and treated with a combination of local surgery and systemic chemotherapy. She received six courses of CMF (cyclphosphamide, methotrexate and fluorouracil) until October 1987. On admission her serum sodium was $141 \mathrm{mmol} / \mathrm{l}$ with a serum albumin of $40 \mathrm{~g} / \mathrm{l}$, bilirubin $77 \mu \mathrm{mol} / \mathrm{l}$ and an AST of 1265 IU/l. Liver biopsy showed acute hepatitis B with no evidence of cirrhosis or delta virus. A small focus of poorly differentiated adenocarcinoma was also detected in the biopsy. Despite supportive therapy she deteriorated rapidly and developed ascites, encephalopathy, and heptorenal syndrome. In the terminal stages of her illness she developed hyponatraemia unresponsive to large quantities of $20 \%$ albumin infused intravenously (Fig 4).

\section{Discussion}

In three of the four patients described above hyponatraemia responded to the intravenous infusion of albumin solutions. The three who responded all had decompensated cirrhosis and hepatocellular failure whereas the patient who did not respond had fulminant hepatic failure caused by acute hepatitis $B$ in the absence of cirrhosis. The pathogenesis of hyponatraemia may be different in the two circumstances. There is evidence that the leucocyte sodium potassium ATPase (sodium pump) is impaired in patients with fulminant hepatic failure causing a sick cell syndrome as in case four. "In contrast recent work from our hospital has shown that in most cirrhotics with hyponatraemia the sodium pump is hyperactive with an increased sodium efflux rate constant and a decreased intracellular sodium concentrate compared with controls. ${ }^{12}$ The sodium pump may be stimulated in response to a decreased effective circulating blood volume because of peripheral arterial vasodilation. ${ }^{13}$
Albumin infusion may improve hyponatraemia because of relative intravascular dehydration but would be unlikely to help in hyponatraemia secondary to the sick cell sydrome.

There is evidence that increasing the intravascular volume corrects many of the fluid and electrolyte problems in patients with cirrhosis. Repleting intravascular volume by head-out water immersion ${ }^{3}$ or by infusing saline ${ }^{14}$ or albumin and saline ${ }^{8}$ is followed by an increase in urinary free water clearance in many cirrhotic patients. The fact that a significant fraction of infused albumin rapidly leaks out into the extravascular space in cirrhotic patients ${ }^{15}$ may explain why albumin had to be given repeatedly to maintain the serum sodium level in patient 1 . This is best given as $20 \%$ albumin as this involves the infusion of less sodium chloride and therefore less risk of aggravating ascites.

The alternatives to intravenous albumin infusions in hyponatraemic patients include fluid restriction, ${ }^{3}$ peritoneal dialysis, ${ }^{4}$ haemofiltration, ${ }^{5}$ oral urea ${ }^{6}$ or oral tetracycline. ${ }^{7}$ Vigorous fluid restriction is unpleasant and may prove impossible if the patient is encephalopathic or otherwise uncooperative. Oral urea is unpleasant to take, causes diarrhoea and is relatively ineffective. ${ }^{16}$ Demeclocycline is more effective but may be nephrotoxic. ${ }^{7}$ Peritoneal dialysis has been reported to be very effective by RingLarsen et al. ${ }^{4}$ All patients in their study, however, also received significant amounts, 200 to $300 \mathrm{~g}$ of intravenous albumin, to compensate for protein loss in the dialysate. We suggest that the improvement in serum sodium in their study may have been due, at least in part, to the albumin infusion and that perhaps peritoneal dialysis was unnecessary.

Albumin infusion does not correct the basic underlying cause of the hypontraemia and thus the effects are temporary. If the patient is being considered for liver transplantation, however, as in patients 1 and 2, temporary correction of hyponatraemia may be advantageous. Correction of hyponatraemia preoperatively may prevent some of the neurological complications seen after transplantation. ${ }^{17}$ It may also be useful when the hyponatraemia has been aggravated by diuretic therapy as in patient three and symptoms demand that the electrolyte disorder be corrected relatively quickly.

1 Arroyo V, Rodes J, Guiterrez-Lizarraga MA, Revert L. Prognostic value of spontaneous hyponatraemia in cirrhosis with ascites. Dig Dis Sci 1976; 21: 249-56.

2 Arieff AI, Llach F, Massry SG. Neurological manifestation and morbidity of hyponatraemia: correlation with brain water and electrolytes. Medicine 1976; 55: 121-29.

3 Epstein M. Derangements of renal water handling in liver disease. Gastroenterology 1985; 89: 1415-25.

4 Ring-Larsen H, Clausen E, Ranek L. Peritoneal dialysis in hyponatraemia due to liver failure. Scand 7 Gastroenterol hyponatraemia

5 Larner AJ, Vickers CR, Adu D, Buckels JAC, Elias E, Neuberger J. Correction of severe hyponatraemia by continuous arteriovenous haemofiltration before liver transplantation. BrMed F 1988; 297: 1514-5.

6 Decaux G, Mols P, Guachi P, Delwiche F. Use of urea for treatment of water retention in hyponatraemic cirrhosis with ascites resistant to diuretics. $\mathrm{Br}$ Med $\mathcal{F}$ 1985; 290: 1782-3.

7 Perez-Ayuso RM, Arroyo V, Camps J, et al. Effect of demeclocycline on renal function and urinary prostaglandin E2 and kallikrein in hyponatraemic cirrhotics. Nephron 1984; 36: 30-7.

8 Vlahcevic ZR, Adham NF, Jick H, Moore EW, Chalmers TC. Renal effects of acute expansion of plasma volume in cirrhosis. N Engl f Med 1965; 272: 387-91.

9 Dandona P, Fonseca V, Baron DN. Hypoalbuminaemic 
hyponatraemia: a new syndrome? $\mathrm{Br}$ Med $\mathcal{f} 1985$; 291: 1253-5.

10 Pugh RNH, Murray-Lyon IM, Dawson JL, et al. Transection of the oesophagus for bleeding oesophageal varices. $B r \mathcal{F}$ Surg 1973; 60: 646-9.

11 Alam AN, Wilkinson SP, Poston L, Moodie H, Williams R. Intracellular electrolyte abnormalities in fulminant hepatic Intracellular electrolyte abnormalities in
failure. Gastroenterology 1977; 72: $914-7$.

12 Cameron ID, Baron DN. Leucocyte electrolytes and sodium pump activity in hyponatraemic cirrhotics with ascites. pump activity in hyponatraemic cirrhotics

13 Schrier RW, Arroyo V, Bernardi M, Epstein M, Henriksen JH, Rodes J. Peripheral arterial vasodilation hypothesis: a proposal for the initiation of renal sodium and water retention in cirrhosis. Hepatology 1988; 8: 1151-7.

14 Schendl HP, Bartter FC. An explanation for an experimenta correction of the abnormal water diuresis in cirrhosis. $\mathcal{F}$ Clin Invest 1960; 39: 248-61.

15 Parving HH, Ranek L, Lassen NA. Increased transcapillary escape rate of albumin in patients with cirrhosis of the liver. Scand F Clin Lab Invest 1977; 37: 643-8.

16 Hayes PC, Williams R. Oral urea in the treatment of hyponatraemic ascites. [Abstract]. Gut 1988; 28: A1386.

17 Adams RH, Ponsford S, Gunson B, et al. Neurological Adams RH, Ponsford S, Gunson B, et al. Neurological
complications following liver transplantation. Lancet 1987; i: $949-51$ 